
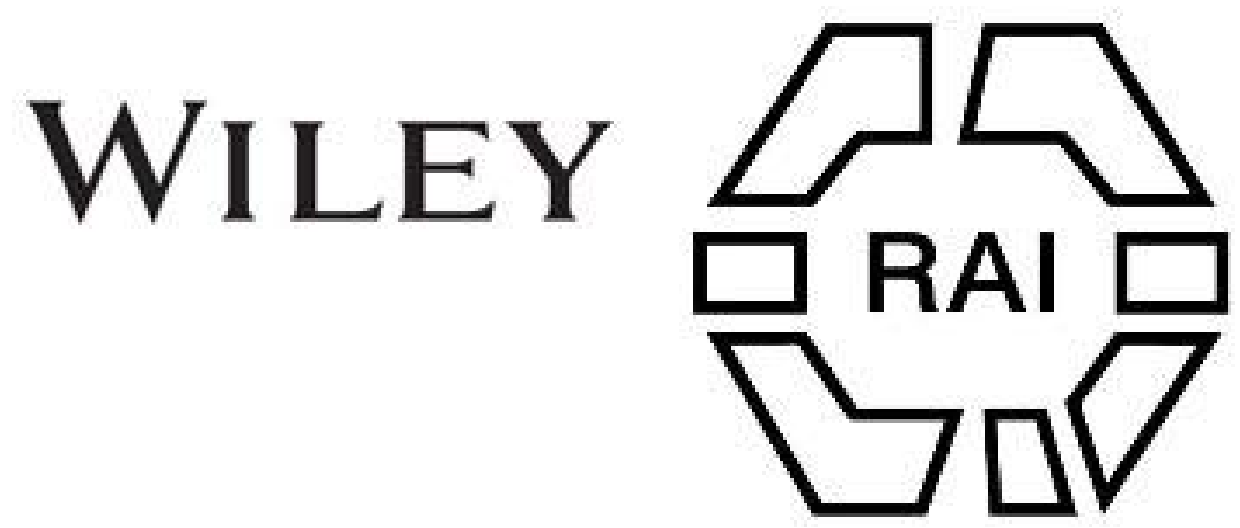

\title{
14. Note on the Relative Variability of Modern and Ancient, and of Rural and Urban
} Peoples.

Author(s): Charles S. Myers

Source: Man, Vol. 6 (1906), pp. 24-26

Published by: Royal Anthropological Institute of Great Britain and Ireland Stable URL: http://www.jstor.org/stable/2788531

Accessed: 27-06-2016 03:58 UTC

\footnotetext{
Your use of the JSTOR archive indicates your acceptance of the Terms \& Conditions of Use, available at http://about.jstor.org/terms
}

JSTOR is a not-for-profit service that helps scholars, researchers, and students discover, use, and build upon a wide range of content in a trusted digital archive. We use information technology and tools to increase productivity and facilitate new forms of scholarship. For more information about JSTOR, please contact support@ jstor.org.

Wiley, Royal Anthropological Institute of Great Britain and Ireland are collaborating with JSTOR to digitize, preserve and extend access to Man 
the case generally, from such evidence as I have. The skull was crushed beyond hope of reconstruction, but half the lower jaw, the right-hand portion, was fairly preserved. It contained three healthy teeth, remarkable for their perfectly flat upper surface.

On sorting out all the contents of the grave, I managed to separate out the remains of no less than fifteen bone harpoons, all broken small, made of the bones of some animal, probably the guanaco. The marks of the tool with which they had been scraped to a point were clearly visible. None of these were barbed, whilst the natural curve in those fashioned from rib bones must have rendered them but inefficient implements, whether of war or the chase. Only one arrow-head was present, not remarkable in any way; it was of a common lanceolate form and poor material.

The most interesting object found in this grave was a necklace, the scattered beads of which had to be recovered by treating the whole contents of the grave in a sieve. By this means considerably more than a thousand tiny dises of shell were obtained, all perforated in their centres and forming, when threaded, a string 6 feet long. Many were lost through their decayed state. Each of these must have been drilled alone, since the perforation is funnel-shaped from each side. The drills used may possibly have been the tough, hard spines of the cactus.

Finally, whilst searching for the beads, I found a few fragments of bone, of irregular shape, stained a bright turquoise blue colour by means of copper, as I determined subsequently. This colouration was distinctly confined to these few fragments, and did not affect the other bones in the least. I could find no copper bearing stone in the rubbish that could bave caused a stain by contact, so am iuclined to consider that the colouring was done purposely.

OSW ALD H. EVANS.

New Zealand.

Edge-Partington.

Note on the Maori Canoe Baler, described by H. St. George Gray in "Man," 1906, 5. By J. Edge-Partington.

The canoe baler figured and described by Mr. St. George Gray in his note in MAN, 1906, 5, is certainly of interest, but rather on account of the unusual style of carving than from the history which accompanies it. The treatment of the human face carved on the end is quite peculiar and without parallel among the specimens of Maori art which are known to collectors; it is far too realistic for old Maori work and the details, nose, ears, grooved tongue, taken by themselves would hardly suggest New Zealand work at all. Finally, the position of the face is a contradiction to the conventional phallic idea generally expressed in the handles of these balers.

It seems difficult, therefore, to agree with Mr. Gray when he writes, "There is " nothing unusual about the treatment of the decorated portion of the baler."

I do not wish to be understood to imply any doubt as to the genuine nature of the baler itself, there can, in fact, be none; but it is difficult not to believe that the ornamentation is quite modern and possibly even the handiwork of a European.

J. EDGE-PARTINGTON.

Craniology.

Myers.

Note on the Relative Variability of Modern and Ancient, and 14
f Rural and Urban Peoples. By Charles S. Myers.

In a paper published in the Journal of the Anthropological Institute (Volume XXXV., page 80) I have pointed out that the chief head measurements show approximately the same variability in the "prehistoric" people of Upper Egypt as in the modern population of the same region. One is led to conclude that age alone does not produce in a people increased heterogeneity. 
There are at least two other instances which indicate a similar conclusion. They are published mainly in Professor Karl Pearson's The Chances of Death and Other Essays (Vol. I., page 290). As they refer only to the cephalic index, I leave the comparison of other head measurements to my paper mentioned above.

I may add that the co-efficient of variability is a hundred times the ratio of the standard deviation to the average, and that the standard deviation is the square root of the sum of the squares of the differences of the measurements from their mean divided by the total number of measurements $\left(\sqrt{\frac{\overline{\Sigma a^{2}}}{n}}\right)$.

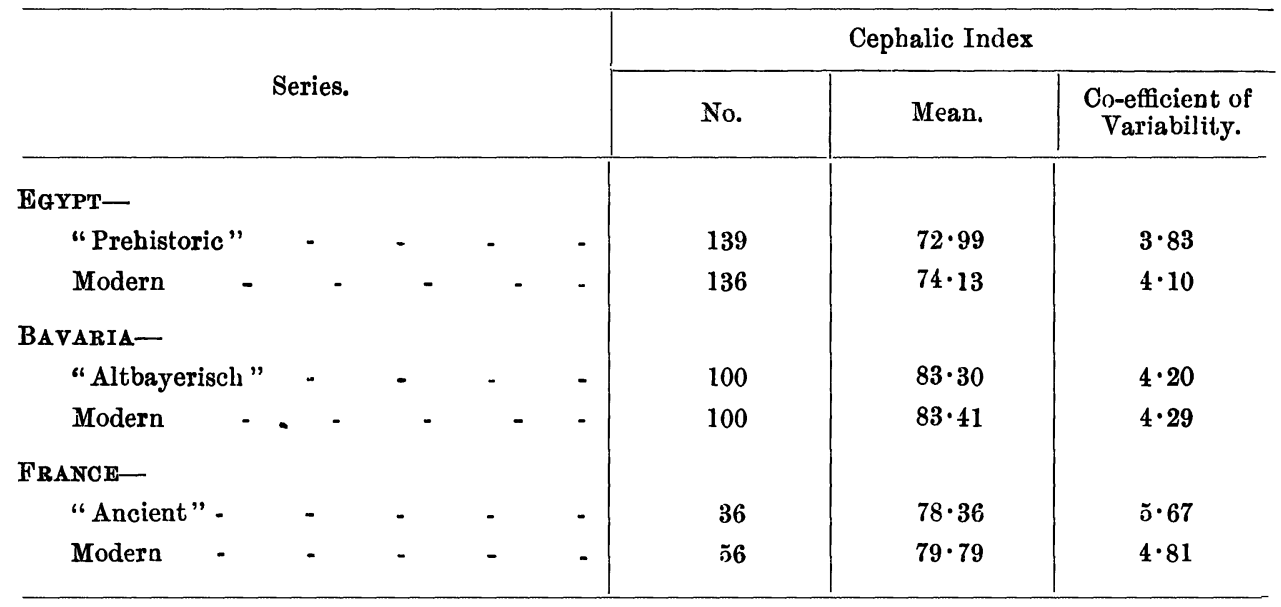

In the same paper I have also pointed out how much more variable the inhabitants of a populous city are than those of country villages, and that in comparing communities of different regions or periods care must be taken to be sure that in this respect they are truly comparable. The following table shows the greater variability of townsfolk :-

\begin{tabular}{|c|c|c|c|c|}
\hline \multirow{2}{*}{\multicolumn{2}{|c|}{ Series. }} & \multicolumn{3}{|c|}{ Co-efficients of Variability. } \\
\hline & & Head-Length. & Head-Breadth & Cephalic Index. \\
\hline \multicolumn{2}{|l|}{ ANCIENT EGYPT- } & & & \\
\hline \multicolumn{2}{|c|}{ Kena peasants (Naḳada, 4000-1000 B.C.) - } & $3 \cdot 11$ & $3 \cdot 29$ & $3 \cdot 83$ \\
\hline \multicolumn{2}{|c|}{ Kena townsfolk (Thebes, $600-2000$ B.c.) - } & $3 \cdot \tilde{y} t$ & - & $4 \cdot 46$ \\
\hline \multicolumn{5}{|l|}{ MODERN EGYPT- } \\
\hline Giza peasants (recruits, modern) & - & $3 \cdot 08$ & $2 \cdot 83$ & $3 \cdot 33$ \\
\hline Giza townsfolk (Cairo, modern) & - & $4 \cdot \tilde{0} 4$ & $4 \cdot 85$ & $7 \cdot 01$ \\
\hline \multicolumn{5}{|l|}{ MODERN GERMANY- } \\
\hline Bavarian peasants - & - & - & - & $4 \cdot 29$ \\
\hline Bavarian townsfolk (Munich) & - & - & - & $6 \cdot 50$ \\
\hline \multicolumn{5}{|l|}{ Modern France- } \\
\hline French peasants - & - & - & - & $4 \cdot 81$ \\
\hline French townsfolk (Paris) & - & -- & -- & $5 \cdot 63$ \\
\hline
\end{tabular}

The data concerning "prehistoric" Egypt are extracted from Miss Faw cett's valuable memoir (Biometrika, Vol. I., pp. 408-467); those relating to France and Germany are due to Professor Karl Pearson (op. cit., etc.). In some instances the probable errors of 
the co efficients must be high, owing to the small number of measurements within the series. But it is to be hoped that this note may induce others to study the relative variability of modern and ancient and of rural and urban peoples, and the various conditions affecting it.

CHARLES S. MYERS.

India, South.

Annandale.

The Introduction of the Blow-Gun into Southern India. By N. Annandale, D.Sc., Indian Museum, Calcutta.

During a recent visit to the Ramnad estate, on the Indian shore of the Gulf of Manaar and Palk's Straits, I was surprised to hear that among the unorthodox Muhammedans known locally as "Lubbais," men not uncommonly make a livelihood by shooting pigenns with blow-guns. There has long been intercourse (which is still conducted in native boats) between these people and the ports of the Straits Settlements, and I was able, at a place called Kilakarai, to carry on a conversation in Malay with the owner of a blow-gun, which he finally sold me. According to his statement, blow-guns are bought from "orang Bugis" in Singapore and carried home in schooners, built and owned by Tamils, to Kilakarai and the neighbouring ports. 'The specimen, which I hope to describe in detail shortly in the Memoirs of the Asiatic Society of Bengal, is evidently of North Bornean workmanship, with certain alterations made in India. 'The tube is of palm wood, single, artificially bored, finely polished outside, and decorated, in characteristic patterns, with an inlay of tin, the mouth-piece being of the same metal. Little pellets of unbaked clay were used with it instead of darts. The local name of the blow-gun is sĕnggūtān, derived, in popular etymology, from the Tamil words sĕn, above, and $k \bar{u} t \bar{u}$, to stab ; really, there can be little doubt, a corruption of the common Malay name of the weapon, viz., sümpittun.

N. ANNANDALE.

\section{Philippines.}

Thomas.

Note on a ms. in the British Museum. By $N$. W. Thomas, M.A.

Dr. Brinton, on p. 45 of his South American Languages, 1892, quotes from fol. 53 of a Spanish MS. in the British Museum (Add. MSS. No. 17,631) a vocabulary which he referred to Patagonia, though he was unable to show that it had affinities with any Patagonian language. He also states that the same numerals are given in another vocabulary which, however, differs widely in some of the words, but is evidently allied to the Tsoneca tongue. This latter vocabulary is, he says, denominated Ilongote in the MS. In his Record of Study, published six years later, he corrected this statement by referring the "Ilongote" language to the North Pacific coast.

As a matter of fact the numerals published by Dr. Brinton do not appear in any other vocabulary in the British Museum. The second vocabulary to which he refers has no connection with the first, and neither of them is denominated "Ilongote" in the MS. On fol. 51 are notes on the Ilongotes of the Philippines and a vocabulary; on fol. 52 a vocabulary from Port Mulgrave, Alaska, which I propose to publish later; and on fol. 53 the vocabulary published by Dr. Brinton, with some errors of transcription (gadyocoye for gaayocoye, chavin for chagui, teus for tkus (?), tasabay for tajabay, amts for Jamts, and a sentence omitted) with the endorsement "a la Goleta" (according to Brinton, Soleta). The fact that the word canoe appeared in the vocabulary should have made it clear that it is unlikely to be S. American, and Goleta (near Santa Barbara, California) should have suggested the real provenience of the vocabulary, the numerals of which seem to be those of a language of Washington territory, or perhaps of Salish, though with many inaccuracies.

More remarkable still was the failure to read this plainly written "Ilongote" and to infer the East Asiatic origin of the notes from a mention of the nose-flute and the Tagalos, or from the obviously Malay character of the vocabulary. 